\title{
TERAPI KOGNITIF PERILAKU UNTUK MEREDUKSI TINGKAT KECEMASAN PADA PASIEN PASCA STROKE
}

\section{COGNITIVE BEHAVIOR THERAPY TO REDUCE THE PATIENT'S POST STROKE ANXIETY}

\author{
Susanti Prasetyaningrum \\ Siti Suminarti Fasikhah \\ Diah Karmiyati \\ Fakultas Psikologi Universitas Muhammadiyah Malang \\ E-mail: santiwahyudi20@gmail.com
}

\begin{abstract}
Patient's post-stroke anxiety can be identified by observing their cognitive, physical, emotional, and behavioral characteristics. Basically, it is impossible to eliminate the anxiety permanently, but reduce it by conducting some therapies. One of the therapies is cognitive behavior therapy with via letting go relaxation technique, cognitive restructuring, and exposure with response prevention. The therapy aims at reducing the anxiety indicated by the decrease of anxiety level and negative thought frequency, the ability to create more positive, rational, and healthier thought, and more adaptive behavior. The single case study employed ABA design. The research subjects were two patients suffering from poststroke anxiety determine by Subjective Units of Discomfort Scale (SUDs), Beck Anxiety Inventory $(B A l)$, and recognized characteristic of post stroke anxiety. The study was conducted in some stages, namely pre therapy, therapy, post therapy, and follow up in seven sessions. Afterwards, three-week monitoring program was conducted to observe the subject's condition after therapy termination. The first subject was treated by 2 session via letting go relaxation therapy technique, 2 session cognitive restructuring, and 3 session exposure. Meanwhile, the second subject was treated by 3 session via letting go relaxation therapy technique, 2 session cognitive restructuring, 2 session exposure. The study used Subjective Units of Discomfort Scale (SUDs), Beck Anxiety Inventory (BAI), and the self monitoring as the research instrument. The findings showed that cognitive behavior therapy significantly reduced the patient's post stroke anxiety.
\end{abstract}

Key words: Cognitive Behavior Therapy, Anxiety, Post-Stroke 


\section{ABSTRAK}

Kecemasan pasien pasca stroke dapat diketahui dari ciri-ciri yang ditunjukkan, yaitu ciri kognitif, fisik, emosi, dan perilaku. Kecemasan pada dasarnya tidak dapat hilang sama sekali, tetapi kecemasan dapat direduksi dengan beberapa terapi. Salah satu yang dapat digunakan adalah terapi kognitif perilaku dengan teknik relaksasi via letting go, restrukturisasi kognitif, dan exposure with response prevention. Tujuan dari terapi ini adalah mereduksi tingkat kecemasan dengan ditandai oleh menurunnya tingkat kecemasan dan frekuensi munculnya pemikiran negatif, perubahan pemikiran negatif menjadi postif, rasional, dan sehat, dan perubahan perilaku yang lebih adaptif. Penelitian ini merupakan penelitian kasus tunggal. Desain dalam penelitian ini menggunakan desain ABA. Subjek dalam penelitian ini berjumlah dua orang yang pernah sakit stroke dan mengalami kecemasan. Pemilihan subjek yang mengalami kecemasan dilihat dengan skala Subjective Units of Discomfort (SUDs), Beck Anxiety Inventory (BAl), dan ciri-ciri kecemasan pada pasien pasca stroke. Penelitian dilakukan mulai dari pra terapi, terapi, pasca terapi, dan tindak lanjut selama tujuh sesi dan tiga minggu setelah terapi untuk memantau kondisi subjek. Pada subjek pertama teknik relaksasi Via letting go diberikan dalam dua sesi, restrukturisasi kognitif duasesi, dan exposure tiga sesi. Untuk subjek kedua relaksasi cia letting go sebanyak tiga sesi, restrukturisasi kognitif dua sesi, dan exposure dua sesi. Alat ukur yang digunakan dalam penelitian ini adalah SUDs, BAI, dan self monitoring. Hasil penelitian ini menunjukkan bahwa terapi kognitif perilaku mampu mereduksi tingkat kecemasan pada pasien pasca stroke.

Kata Kunci: Terapi kognitif perilaku, Kecemasan, Pasca Stroke

Kesehatan fisik maupun psikologis menjadi salah satu tujuan yang utama dalam kehidupan manusia. Kesehatan fisik manusia dipengaruhi oleh kesehatan psikologis. Begitu juga sebaliknya. Dengan demikian, antara kesehatan fisik dan psikologis menjadi saling berkaitan. Friedman dan Miriam (2006) mengungkapkan bahwa fisik, psikologis, dan sosial merupakan suatu kesatuan yang utuh dalam diri manusia. Apabila kesehatan fisiknya terganggu, maka dapat memengaruhi kesehatan psikologis, sehingga kesehatan harus sejalan antara fisik dan psikologis.

Ada beberapa penyakit yang sangat erat kaitanya dengan tingkat kesehatan psikologis, misalnya asma, tekanan darah tinggi, penyakit jantung koroner, kanker, dan stroke. Penyakit tersebut memengaruhi sistem kekebalan tubuh dan perasaan (Fausiah \& Widury, 2005). Dari beberapa penyakit yang disebutkan, penyakit stroke masih menempati urutan teratas sebagai penyakit yang memengaruhi kondisi psikologis seseorang (Bogousslavsky, 2002).

Jumlah penderita stroke meningkat dari tahun ke tahun, seperti ditunjukkan oleh hasil survei dari Organisasi Kesehatan Dunia (WHO). Hasil survei tersebut menunjukkan data pada tahun 2001 sebanyak 20,5 juta jiwa di dunia terkena penyakit stroke dan 5,5 juta manusia telah 
meninggal dunia. Selanjutnya data survei Kesehatan Rumah Tangga Departemen Kesehatan RI tahun 1995 menunjukkan bahwa penyakit stroke merupakan penyebab kematian ketiga setelah jantung dan kanker. Sebanyak $28,5 \%$ penderita stroke meninggal dunia, sedangkan sisanya menderita kelumpuhan sebagian maupun total. Hanya $15 \%$ penderita yang dapat sembuh total dari serangan stroke atau kecacatan (Tjokroprawiro, 2007).

Pada perkembanganya penyakit stroke tidak hanya menyerang kelompok lanjut usia. Seiring dengan perkembangan dan perubahan zaman, dewasa ini ada kecenderungan bahwa stroke mulai diderita oleh kelompok usia produktif, yaitu di bawah usia 45 tahun. Masskulpan, dkk. (2008) menjelaskan bahwa terdapat kecenderungan peningkatan jumlah penderita stroke dalam tiap tahunnya dan sebagian kecil yang terkena adalah generasi muda.

Selain itu, stroke juga menimbulkan dampak yang sangat besar dari segi ekonomi dan sosial. Dari segi ekonomi dapat diungkapkan bahwa biaya medis untuk perawatan dan pengobatan sangat tinggi. Sedangkan dari segi sosial penderita pasca stroke yang mengalami kelumpuhan tidak dapat bekerja kembali seperti sebelum terkena stroke sehingga menjadi tidak produktif lagi (Pandji, 2011).

Beberapa penelitian Rudd, dkk. (2007) menghasilkan data bahwa pasien pasca stroke cenderung memunculkan rasa takut ketika akan berkomunikasi dengan orang lain. Ketakutannya dapat berupa ketakutan perkataannya tidak dapat dimengerti orang lain, sehingga muncul perasaan malu. Selain itu perubahan fisik karena kelumpuhan menjadikan pasien pasca stroke kesulitan untuk mengerjakan pekerjaan yang ada di tempat kerjanya sehingga sebagian memilih untuk berhenti dari pekerjaanya. Perubahan-perubahan tersebut dapat memunculkan kecemasan pada pasien pasca stroke.

Kecemasan merupakan perasaan gelisah atau khawatir dan ketakutan terhadap sesuatu situasi khusus yang akan terjadi dengan akibat yang tidak pasti (Ormrod, 2004). Individu tidak yakin akan bahaya yang akan terjadi, di mana dan kapan waktunya (Kalat, 2007). Model kecemasan Beck (Blackburn \& Davison, 1994) merupakan model yang menghubungkan faktor emosi dan pikiran dengan gangguan kecemasan. Menurut Beck (1976), individu mengalami distress psikologis ketika menjadikan situasi yang mengancam sebagai perhatian utamanya.

Menurut Ormrod (2004), terdapat empat aspek yang menyertai kecemasan, yaitu aspek kognitif, afektif, fisiologis, dan perilaku. Aspek kognitif meliputi pikiran yang menakutkan, kekhawatiran, dan pikiran-pikiran negatif. Aspek afektif misalnya perasaan tegang. Aspek fisiologis meliputi peningkatan denyut 
jantung, tekanan darah, pernafasan dan proses fisiologis lainnya. Aspek perilaku ditunjukkan melalui perilaku gelisah dan berjalan bolak-balik (Greenberg, 2002; Ormrod, 2004).

Kecemasan sebagai bentuk hambatan emosi terjadi karena adanya penilaian kognitif yang tidak tepat terhadap stresor. Penilaian kognitif tersebut dibagi menjadi dua, yaitu penilaian primer dan sekunder. Penilaian primer menekankan pada halhal yang berkaitan dengan kesejahteraan diri sendiri dan penilaian terhadap situasi sebagai ancaman atau bukan. Penilaian sekunder menekankan pada pilihan koping atau sumber-sumber yang dimiliki individu (Blackburn \& Davidson, 1994; Lazarus, 1991). Jika individu mampu memberikan penilaian kognitif secara tepat, maka kecemasan tidak akan terjadi.

Berdasarkan pada penelitian Rudd, dkk., (2007) diketahui bahwa empat dari sepuluh pasien pasca stroke mengalami stres akut, kecemasan kronis, bahkan depresi. Kecemasan kronis ditandai oleh munculnya kekhawatiran terhadap aspek kehidupan sehari-hari. Sebagian besar pasien memiliki kekhawatiran dalam pikiran yang cenderung negatif, misalnya takut menghadapi masa depan, kekhawatiran terhadap keluarga, pekerjaan, dan kehilangan rasa hormat dari lingkungan sekitarnya.

Dampak kecemasan pada pasien pasca stroke dapat menganggu proses pemulihan pasien. Rudd, dkk. (2007) menyatakan pasien pasca stroke yang mengalami kecemasan cenderung lebih lama dirawat di rumah sakit dan kurang termotivasi untuk menjalani rehabilitasi sehingga pemulihan untuk sembuh juga sangat lama. Pasien pasca stroke yang memiliki kecemasan menunjukkan ketegangan dalam saraf-sarafnya karena memiliki perasaan berada pada situasi yang mengancam akibat dari perubahan kondisi kehidupan. Kecemasan dapat berkembang menjadi penyakit fisik dan gangguan yang lain apabila tidak mendapat penanganan dengan baik.

Akibat lain kecemasan pasien pasca stroke dapat dijelaskan dari segi faal. Seseorang yang mengalami kecemasan akan meningkatkan denyut jantungnya (Guyton, 1982). Guyton menemukan bahwa setelah mengalami stroke kemampuan jantung untuk memompa darah secara efisien ke seluruh tubuh turun secara signifikan. Bila kecemasan berlanjut dan berlangsung dalam jangka waktu yang lama, maka efisiensi pemompaan jantung akan turun lebih jauh lagi, sehingga beresiko mengalami gangguan ritme jantung (arrhythmia) yang sangat berbahaya. Gangguan ritme jantung menyebabkan suplai oksigen ke otak berkurang, sel-sel otak yang kekurangan oksigen berkurang, sehingga tidak dapat melakukan fungsinya dengan sempurna. Apabila kejadian ini berlangsung lama, maka akan menyebabkan serangan stroke iskemik (stroke non pendarahan) sehingga dapat terjadi serangan stroke kedua kalinya pada pasien pasca stroke. 
Melihat dampaknya yang cukup menganggu bagi subjek pasca stroke yang mengalami kecemasan, maka sangat dibutuhkan penanganan yang tepat. Selanjutnya para penderita ini sebagian besar kurang menyadari adanya gangguan kecemasan dalam dirinya sehingga tidak mengetahui bagaimana cara untuk mengatasinya. Keadaan ini berpotensi menambah perasaan cemas bila hal tersebut tidak tertangani dengan baik.

Penelitian terkait penerapan terapi untuk menurunkan tingkat kecemasan pada pasien pasca stroke belum banyak dilakukan, sehingga untuk membantu pasien pasca stroke mengatasi kecemasannya dapat digunakan salah satu dari beberapa terapi untuk menangani gangguan kecemasan pada pasien penyakit kronis. Beberapa terapi yang direkomendasikan tersebut antara lain terapi humanistik, terapi perilau, terapi kognitif, dan terapi kognitif perilaku (Laidlaw, dkk., 2003; O'Donodue \& Fisher, 2008).

Penerapan terapi kognitif perilaku untuk mengurangi tingkat kecemasan selaras dengan penelitian yang dilakukan Newman, dkk. (2008). Penelitian ini mengambil 18 responden penderita hipertensi yang berusia antara 18-40 tahun dan dilakukan sebanyak 14 sesi. Hasil penelitian terapi kognitif perilaku kombinasi supportive listening untuk mengurangi kecemasan menunjukkan bahwa sebelum dilakukan terapi (prates) kecemasan sebesar $66,7 \%$ dan setelah dilakukan terapi (pascates) kecemasan turun menjadi 33,3\%. Selanjutnya penerapan terapi kognitif perilaku dengan kombinasi terapi emosi interpersonal menunjukkan hasil bahwa sebelum terapi dilakukan tingkat kecemasan sebesar $84,1 \%$ dan setelah dilakukan terapi tingkat kecemasan menjadi sebesar $76,3 \%$.

Beberapa penelitian pada pasien kecemasan menunjukkan terapi kognitif perilaku dapat menurunkan kecemasan. Sauter, dkk. (2009) memberikan terapi ini terhadap responden usia 12-18 tahun dengan gangguan kecemasan setelah mengalami penyakit kronis, seperti kanker, jantung, dan diabetes. Terapi ini terbukti memberikan perubahan secara signifikan dalam mengatasi kecemasan. Otto, dkk. (2004) juga menggunakan terapi kognitif perilaku untuk menangani 33 pasien gangguan kecemasan. Hasil penelitian menunjukkan adanya perubahan hasil, yaitu sebelum dilakukan terapi kecemasan sebesar 60,8\% dan setelah dilakukan terapi turun menjadi $37,3 \%$.

Beberapa hasil penelitian di atas menunjukkan keefektifan terapi kognitif perilaku pada pasien penyakit kronis dengan kecemasan. Dalam penelitian ini terapi kognitif perilaku yang akan diberikan pada pasien pasca stroke terdiri dari tiga teknik, yaitu relaksasi via letting go, restrukturisasi kognitif, dan exposure with response prevention. Ketiga teknik ini 
didasarkan pada gejala-gejala kecemasan yang ditunjukkan oleh kedua subjek penelitian. Ketiga teknik dilakukan secara berurutan, yaitu relaksasi via letting go, restrukturisasi kognitif, dan exposure with response prevention.

Tujuan dalam penelitian ini adalah untuk mengetahui penerapan terapi kognitif perilaku dalam mereduksi kecemasan pada pasien pasca stroke. Hipotesis yang diajukan dalam penelitian ini adalah terapi kognitif perilaku dapat mereduksi tingkat kecemasan pada pasien pasca stroke.

\section{METODE PENELITIAN}

\section{Subjek Penelitian}

Subjek penelitian berjumlah dua orang yang masing-masing akan mendapatkan terapi kognitif perilaku. Dalam penelitian ini akan diberikan batasan dalam pemilihan subjek yang disebut dengan karakteristik subjek. Karakteristik subjek yang diperlukan dalam penelitian ini adalah:

1. Pasien pasca stroke

2. Jenis kelamin laki-laki dan perempuan

3. Rentang usia 45-menjelang 60 tahun

4. Masih mampu berkomunikasi dengan baik

5. Subjek penelitian menunjukkan kecemasan pada pasien pasca stroke. Kecemasan dapat dilihat dari gejala kognitif, fisik, emosi, dan perilaku. Selain itu kecemasan juga dapat dilihat dari pengukuran tingkat kecemasan dengan menggunakan BAI dan SUDs.
6. Subjek penelitian mengalami kelumpuhan atau kecacatan dengan derajat kelumpuhan atau kecacatan 2 dan 3 sesuai dengan derajat kecacatan pasien pasca stroke dari Rankin (Masskulpan, dkk., 2008). Lebih lanjut dijelaskan bahwa derajat kelumpuhan atau kecacatan 2 terbukti saat pasien tidak lagi mampu melakukan beberapa aktivitas seperti sebelumnya, tetapi pasien tetap melakukan sendiri tanpa bantuan. Derajat kecacatan ini berada pada derajat ringan. Selanjutnya derajat kelumpuhan atau kecacatan 3. Pasien memerlukan bantuan, tetapi masih mampu berjalan tanpa bantuan orang lain walaupun dengan menggunakan tongkat. Derajat kecacatan ini berada pada derajat sedang.

7. Bersedia menjadi subjek penelitian dan bekerjasana dalam penelitian.

\section{Desain Penelitian}

Desain yang digunakan dalam penelitian ini adalah $A B A$ design. A adalah fase sebelum terapi, $B$ adalah fase terapi atau intervensi, dan dilanjutkan dengan A, yaitu fase tindak lanjut (Kazdin, 1998).

\section{Metode Pengumpulan Data}

Metode pengumpulan data dalam penelitian ini dengan menggunakan Subjective Unit of Discomfort Scale (SUDs) dan Beck Anxiety Inventory (BAI), dan self monitoring.

SUDs adalah penentuan range tingkat kecemasan berdasarkan apa yang dirasakan subjek (Martin \& Pear, 
2005). Tingkat SUDs dibagi menjadi tiga tingkatan, yaitu tinggi, sedang, dan rendah (Spiegler, 2003). Pengukuran ini dilakukan mulai prates sebelum terapi. Subjek diminta untuk menentukan posisi kecemasan yang dirasakan pada dirinya pada range 0-100, nilai 0-30 merupakan kecemasan rendah, nilai 35-65 kondisi kecemasan sedang, dan nilai 70-100 kondisi kecemasan tinggi (Spiegler, 2003). Kemudian penentuan tingkat ini akan selalu ditanyakan pada akhir sesi, agar terapis maupun subjek dapat mengetahui sudah sejauh mana perkembangan yang terjadi.

Selanjutnya Beck Anxiety Inventory (BAI) yang digunakan adalah yang dikembangkan oleh Aaron Beck pada tahun 1988, terdiri atas 21 aitem. Masing-masing aitem mempunyai 4 kemungkinan jawaban di antara 0-3. Norma yang digunakan adalah 0-7 pada kategori normal, 8-15 mengindikasikan kecemasan ringan, 1625 mengindikasikan kecemasan sedang, 26-63 mengindikasikan kecemasan berat (Chen, 2008). Pada pelaksanaannya, subjek diminta untuk mengisi form skala untuk mengetahui tingkat kecemasan subjek. Pengisian skala ini dilakukan pada saat pra terapi dan pasca terapi. Skala ini digunakan untuk mengetahui perbedaan tingkat kecemasan subjek sebelum dan sesudah terapi. Skala kecemasan ini dijadikan sebagai acuan alat ukur tingkat kecemasan pada pasien pasca stroke yang mengalami kecemasan. Dalam penelitian ini skala kecemasan diberikan pada saat pra terapi, pasca terapi, dan saat tindak lanjut (follow up). Pada fase pra terapi, skala ini digunakan untuk membantu terapis dalam menetapkan baseline.

Pengumpulan data yang terakhir dilakukan dengan menggunakan self monitoring untuk mengetahui frekuensi munculnya kecemasan dan tingkat kecemasan. Penilaian frekuensi munculnya kecemasan dan tingkat kecemasan merupakan sesuatu yang subjektif berdasarkan dari penilaian klien. Biasanya penilaian yang digunakan selalu pada rentang 0 (tidak merasa terganggu) hingga 100 (batas maksimum yang sangat membuat individu menjadi sangat terganggu) (Steketee \& Neziroglu, 2003). Self monitoring yang digunakan dalam penelitian ini mengacu pada teori tersebut.

\section{Prosedur Intervensi}

Prosedur dalam penelitian ini ada beberapa tahap, antara lain penentuan subjek penelitian, identifikasi kasus, melakukan kontrak penelitian, merancang pelaksanaan intervensi, pelaksanaan intervensi dan pemberian tugas rumah, evaluasi pemberian intervensi.

Penentuan subjek penelitian berdasarkan pada munculnya gejala atau simtom-simtom kecemasan pasien pasca stroke, tingkat kecemasan yang diukur dengan SUDs dan BAI. Pada tahap identifikasi kasus, peneliti melakukan klarifikasi permasalahan utama subjek secara lebih mendalam. Pada tahap ini 
dapat diketahui juga gejala atau simtom kecemasan subjek, pemikiran negatif yang dirasakan, dan perilaku yang muncul sebagai reaksi dari kecemasan. Selanjutnya peneliti menawarkan dan menjelaskan prosedur terapi yang akan dilakukan.

Tahap berikutnya merancang pelaksanaan intervensi, yaitu membuat kesepakatan dengan subjek penelitian menyangkut hal-hal apa saja yang akan dijadikan fokus perubahan dalam terapi, modul, jadwal pelaksanaan terapi, dan tempat terapi. Setelah tahap merancang pelaksanaan, kemudian dilanjutkan dengan tahap pelaksanaan terapi. Tahap pelaksanaan ini dibagi menjadi empat tahap yaitu pra terapi, terapi, pasca terapi, dan tindak lanjut. Pada fase pra terapi dilakukan asesmen permasalahan subjek lebih mendalam dan pengukuran tingkat kecemasan untuk dijadikan sebagai baseline dengan menggunakan SUDs dan BAI. Saat fase terapi dilakukan juga pengukuran tingkat kecemasan dengan SUDs dan subjek diberikan tugas rumah untuk mengisi self monitoring mengenai terapi yang dilakukan secara mandiri. Untuk fase pasca terapi dilakukan satu hari setelah terapi selesai dilakukan. Pada tahap ini tingkat kecemasan subjek juga diukur dengan menggunakan SUDs dan BAI. Selain itu juga dilakukan proses wawancara untuk mengetahui beberapa hal mengenai subjek setelah dihentikan proses terapi. Fase terakhir adalah tindak lanjut yang dilakukan tiga minggu setelah terapi dihentikan. Fase tindak lanjut sendiri dilaksanakan selama tiga hari berturut-turut. Di sini subjek diminta untuk mengisi SUDs dan BAI serta dilakukan juga wawancara.

\section{Metode Analisis Data}

Analisa data dalam penelitian ini dilakukan dengan cara membandingkan tingkat kecemasan subjek dari kondisi awal sebelum mendapatkan terapi (asesmen pra terapi/baseline) sampai dengan sesi tindak lanjut.

Penilaian pada saat terapi dimaksudkan untuk mengetahui tingkat perkembangan kecemasan subjek selama proses terapi berlangsung dan mengidentifikasi perubahan pemikiran dan tingkah laku, faktor-faktor yang mendukung perubahan ataupun hambatan-hambatan apa saja yang muncul dalam diri subjek selama proses terapi berlangsung. Dengan melihat hasil penlilaian pada tahap terapi, dapat diketahui apakah ada penurunan tingkat kecemasan pada subjek.

Selanjutnya, penilaian pada tahap pasca terapi dimaksudkan untuk mengetahui apakah ada perubahan tingkat kecemasan setelah terapi diberikan. Selain itu untuk mengetahui faktor-faktor apa saja yang berperan dalam perubahan. Pada akhirnya dapat diketahui apakah ada peranan terapi kognitif perilaku dalam mereduksi kecemasan pada pasien pasca stroke.

Penilaian pada fase tindak lanjut dilakukan untuk menentukan apakah 
perbaikan yang dicapai selama terapi dipertahankan setelah pemberhentian program. Selain itu untuk mengetahui, apakah penurunan tingkat kecemasan subjek setelah terapi relatif tetap setelah terapi ini dihentikan.

\section{HASIL PENELITIAN}

\section{Identitas Subjek}

Subjek dalam penelitian ini berjumlah dua orang. Berikut ini tabel identitas subjek penelitian.

Tabel 1. Identitas Subjek

\begin{tabular}{llll}
\hline \multicolumn{2}{c}{ Identitas Subjek 1 } & \multicolumn{2}{c}{ Identitas Subjek 2 } \\
\hline Nama (inisial) & : PM & Nama (inisial) & : MS \\
Tempat, tgl lahir & : Situbondo,5-4-1964 & Tempat, tgl lahir & : Malang \\
Usia & $:$ 47 tahun & Usia & $:$ 41 tahun \\
Jenis kelamin & $:$ Laki-laki & Jenis kelamin & : Perempuan \\
Agama & $:$ Islam & Agama & : Islam \\
Pekerjaan & $:$ PNS & Pekerjaan & : PNS \\
Pendidikan & $:$ Sarjana (S1) & Pendidikan & $:$ S2 \\
Alamat & $:$ Malang & Alamat & $:$ Blitar \\
\hline
\end{tabular}

Dari tabel di atas, dapat dilihat bahwa subjek dalam penelitian ini berjumlah dua orang. Subjek yang pertama berjenis kelamin laki-laki, berusia 47 tahun, status menikah dan mempunyai penyakit stroke sejak tahun 2006. Untuk subjek kedua berjenis kelamin perempuan, berusia 41 tahun, status menikah, dan menderita stroke sejak tahun 2008. Subjek pertama mengalami stroke satu kali yang mengakibatkan kelumpuhan pada kaki dan tangan sebelah kiri, kesulitan bicara (pelo), kesulitan mengingat, dan konsentrasi. Sedangkan untuk subjek kedua pernah mengalami stroke dua kali, yaitu pada tahun 2008 dan 2009. Stroke pertama menyebabkan kaki dan tangan kanan mati rasa dan kaku jika digerakkan, bicaranya pelo. Dampak stroke yang kedua kalinya adalah tangan dan kaki kanan lumpuh, bicara pelo, hambatan dalam pendengaran, kesulitan mengingat dan konsentrasi.

Dalam melakukan aktivitas seharihari, kedua subjek ini menggunakan alat bantu. Subjek pertama menggunakan tongkat untuk membantunya berjalan, sedangkan subjek kedua menggunakan alat bantu tongkat juga dan alat bantu pendengaran.

\section{Pelaksanaan Terapi}

Pelaksanaan intervensi dilakukan dalam tiga tahap, yaitu pra terapi, terapi, dan pasca terapi. Jumlah pertemuan untuk intervensi dua subjek dilakukan 
sebanyak tujuh pertemuan. Untuk subjek pertama, tujuh sesi itu dibagi menjadi dua sesi untuk terapi relaksasi, dua sesi terapi restrukturisasi kognitif, dan tiga sesi untuk exposure. Sedangkan untuk subjek kedua, tujuh sesi dibagi menjadi tiga sesi untuk relaksasi, dua sesi restrukturisasi kognitif, dan dua sesi exposure. Perbedaan pertemuan tersebut terjadi karena beberapa faktor, yaitu perkembangan tingkat perubahan reaksi kecemasan yang ditunjukkan oleh subjek, kemampuan subjek dalam memahami proses-proses terapi, motivasi dan keaktifan subjek mengikuti terapi, dan penerapan terapi secara mandiri.

Subjek pertama saat proses terapi lebih fokus terhadap perubahan yang akan dicapai dalam tiap sesi dan mampu untuk memahami instruksi dan prosesproses terapi yang harus dilalui. Tetapi pada saat exposure, sesinya lebih lama karena masih sering muncul pemikiranpemikiran negatifnya. Dengan pemberian tiga sesi exposure, subjek menunjukkan peningkatan perubahan ke arah yang lebih positif. Hasil tersebut bertahan sampai tindak lanjut.

Pada subjek kedua, di awal pertemuan subjek melakukan identifikasi situasi yang memunculkan kecemasan dalam jumlah yang sangat banyak. Subjek juga menyampaikan beberapa fokus terapi yang dijadikan tujuan terapi. Setelah diminta untuk lebih memfokuskan lagi, subjek memilih empat situasi yang sering memunculkan kecemasan. Saat proses terapi, subjek juga memperlihatkan perilaku terlalu tergesa-gesa untuk mengikuti terapi dan ingin segera mencapai hasil yang diinginkannya sehingga hasilnya menjadi kurang maksimal. Setelah diberikan penjelasan mengenai proses-proses terapi yang harus dilalui, subjek menunjukkan hasil yang lebih maksimal. Pada sesi restrukturisasi kognitif dan exposure, subjek mampu menunjukkan perubahan yang cukup baik.

Berdasarkan hasil asesmen, diketahui bahwa kecemasan yang dialami subjek 1 dan 2 disebabkan adanya pemikiran-pemikiran negatif yang muncul dikarenakan penyakit strokenya. Pikiranpikiran negatif tersebut membuat subjek merasa khawatir, takut, cemas, putus asa dan menganggap beberapa hal yang berhubungan dengan pengobatan dan pemulihan kesehatannya tidak berguna.

Hasil terapi yang dilakukan dapat diketahui bahwa subjek mengalami perubahan yang cukup berarti setelah mengikuti terapi setiap sesinya. Perubahan yang dialami subjek adalah perubahan pikiran negatif atau irrasional menjadi pikiran yang lebih rasional, positif, dan sehat. Secara emosional subjek menjadi lebih tenang, nyaman, dan rileks. Selain itu reaksi fisiologis dari kecemasan juga berangsur-angsur berkurang dan menghilang, antara lain pusing, tangan dan kaki kesemutan, jantung berdebar- 
debar, sulit tidur atau mimpi buruk, dan sesak nafas. Hal ini disebabkan kedua subjek mampu mengontrol dan mengendalikan kecemasannya.

Intervensi yang diberikan kepada subjek adalah relaksasi via letting go, restrukturisasi kognitif, dan exposure. Intervensi tersebut memiliki beberapa tujuan, antara lain: 1) memberikan ketrampilan relaksasi kepada subjek supaya mampu menerapkannya pada situasi yang membuatnya cemas sehingga subjek mampu merasakan rileks dan nyaman, 2) membantu subjek untuk melawan dan mengubah pola pikir negatif dan irrasionalnya menjadi pola pikir yang lebih positif, rasional, dan sehat, 3) membantu subjek supaya tidak cemas ketika berhadapan dengan situasi yang mengancam.
Berikut ini perubahan-perubahan yang terjadi sebelum proses intervensi dan setelah intervensi dilakukan.

\section{Perubahan Pemikiran Subjek}

Perubahan pikiran yang dialami subjek dapat diketahui dari perbandingan isi pikiran-pikirannya sebelum dan sesudah menjalani terapi. Sebelum menjalani terapi, isi pikiran subjek berupa ketakutan, kekhawatiran, putus asa, dan tidak berharga. Sesudah menjalani terapi restrukturisasi kognitif, subjek 1 dan 2 dapat berpikir positif dan hal ini membuat subjek merasa jauh lebih tenang dan memahami kondisinya sebagai akibat dari penyakit strokenya. Berikut ini tabel perubahan pemikiran subjek 1 dan 2 setelah melakukan teknik restrukturisasi kognitif.

Tabel 2. Perubahan Pemikiran Subjek

\begin{tabular}{|c|c|c|c|c|c|}
\hline \multicolumn{3}{|c|}{ Subjek 1} & \multicolumn{3}{|c|}{ Subjek 2} \\
\hline Situasi & Sebelum & Sesudah & Situasi & Sebelum & Sesudah \\
\hline $\begin{array}{l}\text { Duduk sendiri, } \\
\text { dan istri tidak } \\
\text { menemani }\end{array}$ & $\begin{array}{l}\text { Takut tiba-tiba } \\
\text { strokenya kam- } \\
\text { buh dan tidak ada } \\
\text { yang tahu } \\
\text { - Jangan-jangan } \\
\text { istri tidak cinta } \\
\text { dan tidak mau } \\
\text { menemani saya }\end{array}$ & $\begin{array}{l}\text { - Saya tidak takut } \\
\text { duduk sendiri, is- } \\
\text { tri dan anak-anak } \\
\text { juga ada di rumah } \\
\text { dan tidak jauh } \\
\text { dengan saya. } \\
\text { - Tidak seharusnya } \\
\text { saya berpikiran } \\
\text { negatif terhadap } \\
\text { istri saya toh } \\
\text { dia sudah sabar } \\
\text { dengan keadaan } \\
\text { saya saat ini. }\end{array}$ & $\begin{array}{l}\text { Saat duduk bersa- } \\
\text { ma dengan suami } \\
\text { dan anak-anak }\end{array}$ & $\begin{array}{l}\text { Jangan-jangan } \\
\text { suami dan anak } \\
\text { malu punya istri } \\
\text { atau ibu yang } \\
\text { lumpuh. Jadi } \\
\text { takut kalo suami } \\
\text { makin menjauh }\end{array}$ & $\begin{array}{l}\text { Saya senang } \\
\text { berkumpul sama } \\
\text { suami dan anak- } \\
\text { anak soalnya } \\
\text { dapat saling cerita } \\
\text { dan bertukar } \\
\text { pikiran. }\end{array}$ \\
\hline
\end{tabular}




\begin{tabular}{|c|c|c|c|c|c|}
\hline $\begin{array}{l}\text { Sore hari duduk } \\
\text { sama istri dan } \\
\text { istri mengajak } \\
\text { cek kesehatan } \\
\text { esok hari }\end{array}$ & $\begin{array}{l}\text { - Takut diperiksa } \\
\text { karena jangan- } \\
\text { jangan strokenya } \\
\text { menjalar ke } \\
\text { seluruh tubuh } \\
\text { - Takut terdapat } \\
\text { anggota tubuh } \\
\text { yang lain yang } \\
\text { terkena stroke } \\
\text { - Takut kondisi } \\
\text { kesehatan yang } \\
\text { sebenarnya, } \\
\text { jangan-jangan } \\
\text { kondisi badan } \\
\text { menjadi menurun }\end{array}$ & $\begin{array}{l}\text { Dengan kontrol } \\
\text { ke rumah sakit } \\
\text { saya dapat tahu } \\
\text { kondisi dan } \\
\text { perkembangan } \\
\text { kesehatan saya. } \\
\text { - Mau diajak } \\
\text { kontrol kesehatan } \\
\text { biar tahu kondisi } \\
\text { sebenarnya } \\
\text { seperti apa. }\end{array}$ & Akan makan & $\begin{array}{l}\text { Saya sakit stroke } \\
\text { ini karena pola } \\
\text { makan yang gak } \\
\text { bener jadi semua } \\
\text { makanan itu } \\
\text { dapat menyebab- } \\
\text { kan stroke. }\end{array}$ & $\begin{array}{l}\text { Saya harus } \\
\text { makan makanan } \\
\text { yang bergizi, } \\
\text { rendah lemak } \\
\text { dan kolesterol. } \\
\text { Sekarang saya } \\
\text { harus ngurangi } \\
\text { makanan yang } \\
\text { dapat menyebab- } \\
\text { kan stroke. }\end{array}$ \\
\hline $\begin{array}{l}\text { Berjalan } \\
\text { dengan dibantu } \\
\text { tongkat }\end{array}$ & $\begin{array}{l}\text { Merasa jadi manusia } \\
\text { paling tidak sem- } \\
\text { purna karena jalan } \\
\text { saja harus tertatih } \\
\text { dan pakai tongkat }\end{array}$ & $\begin{array}{l}\text { Saya memang pakai } \\
\text { tongkat jika berjalan, } \\
\text { kalau tidak saya gak } \\
\text { dapat jalan. Saya } \\
\text { tidak malu keluar } \\
\text { rumah pakai tongkat } \\
\text { karena memang } \\
\text { kondisi saya seperti } \\
\text { ini.. }\end{array}$ & $\begin{array}{l}\text { Mau pakai alat } \\
\text { bantu dengar }\end{array}$ & $\begin{array}{l}\text { Buat apa } \\
\text { pakai alat bantu } \\
\text { dengar, jadi ma- } \\
\text { nusia yang tidak } \\
\text { berguna. Jadi } \\
\text { orang tuli dan } \\
\text { manusia tidak } \\
\text { sempurna karena } \\
\text { mendengar saja } \\
\text { harus pakai alat } \\
\text { bantu. }\end{array}$ & $\begin{array}{l}\text { Dengan alat } \\
\text { bantu ini saya jadi } \\
\text { bisa dengar suara. } \\
\text { Jadi seharusnya } \\
\text { saya tidak minder } \\
\text { dan malu kalau } \\
\text { pakai alat ini. }\end{array}$ \\
\hline $\begin{array}{l}\text { Akan minum } \\
\text { obat }\end{array}$ & $\begin{array}{l}\text { - Tidak bisa jalan } \\
\text { meskipun sudah } \\
\text { meminum obat } \\
\text { - Obat memper- } \\
\text { parah kondisi } \\
\text { badan saya saja } \\
\text { - Tidak ada peruba- } \\
\text { han meskipun } \\
\text { minum obat, toh } \\
\text { juga masih lum- } \\
\text { puh juga. } \\
\text { - Jangan-jangan } \\
\text { strokenya tambah } \\
\text { parah kalo minum } \\
\text { obat terus. }\end{array}$ & $\begin{array}{l}\text { Dengan memi- } \\
\text { num obat secara } \\
\text { teratur secara } \\
\text { berangsur-angsur } \\
\text { kesehatan saya } \\
\text { dapat pulih } \\
\text { kembali. } \\
\text { - Saya harus ber- } \\
\text { pikiran positif ter- } \\
\text { hadap apa yang } \\
\text { dikatakan dokter } \\
\text { untuk minum } \\
\text { obat teratur dan } \\
\text { mengikuti aturan- } \\
\text { aturan dokter. }\end{array}$ & $\begin{array}{l}\text { Suami ngajak } \\
\text { gabung dengan } \\
\text { teman-teman yang } \\
\text { terkena stroke di } \\
\text { tempat fisioterapi }\end{array}$ & $\begin{array}{l}\text { - Malu ber- } \\
\text { temu dengan } \\
\text { teman- } \\
\text { teman karena } \\
\text { saya pasti } \\
\text { satu-satunya } \\
\text { perempuan } \\
\text { yang lumpuh- } \\
\text { nya sangat } \\
\text { parah } \\
\text { - Tidak ada } \\
\text { perubahan } \\
\text { meskipun ikut } \\
\text { fisioterapi }\end{array}$ & $\begin{array}{l}\text { Saya akan men- } \\
\text { coba ikut suami } \\
\text { fisioterapi. Tidak } \\
\text { ada salahnya ikut } \\
\text { fisioterapi untuk } \\
\text { pemulihan kes- } \\
\text { ehatan fisik saya } \\
\text { yang lumpuh. }\end{array}$ \\
\hline $\begin{array}{l}\text { Akan jalan-jalan } \\
\text { pagi }\end{array}$ & $\begin{array}{l}\text { - Jangan-jangan } \\
\text { ada yang melihat } \\
\text { saya jalan pakai } \\
\text { tongkat } \\
\text { - Takut tetangga } \\
\text { dekat melihat ja- } \\
\text { lan pakai tongkat } \\
\text { - Jadi manusia tidak } \\
\text { berguna dan tidak } \\
\text { sempurna karena } \\
\text { jalan saja pakai } \\
\text { tongkat, pasti } \\
\text { orang-orang yang } \\
\text { melihat merasa } \\
\text { kasihan }\end{array}$ & $\begin{array}{l}\text { - Tidak seharusnya } \\
\text { saya malu dan } \\
\text { minder dilihat } \\
\text { orang jalan pakai } \\
\text { tongkat. Seha- } \\
\text { rusnya saya jadi } \\
\text { tambah semangat } \\
\text { lagi. }\end{array}$ & & & \\
\hline
\end{tabular}




\begin{tabular}{lll}
\hline Saat akan & Lauknya ini jangan- & Makan makanan \\
makan & jangan punya dam- & yang beranekaragam \\
pak negatif terhadap & dapat memenuhi \\
kesehatan saya. & kebutuhan gizi dan \\
Takutnya malah & nutrisi yang saya \\
dapat muncul penya- & butuhkan untuk \\
kit gara-gara makan & memulihkan kes- \\
& sayur dan lauk ini. & ehatan saya. \\
\hline
\end{tabular}

2. Perubahan Perilaku Subjek

Perubahan perilaku subjek dimulai saat terapi exposure with response prevention. Sebelum dimulai terapi, pada situasi yang sudah diidentifikasi saat pra terapi, subjek pertama menunjukkan perilaku negatif sebagai konsekuensi dari kecemasannya. Perilaku tersebut misalnya saat situasi akan diajak kontrol ke rumah sakit, subjek memunculkan pemikiran negatif, yaitu jangan-jangan kondisi kesehatannya semakin turun, tidak ada perubahan meskipun kontrol ke rumah sakit, dan sebagainya. Pemikiran tersebut memunculkan reaksi emosional, yaitu ketakutan dan kekhawatiran yang berlebihan sehingga muncul perilaku negatifnya yaitu meremas-remas tangan dan tidak jadi kontrol ke rumah sakit. Perilaku tidak jadi kontrol ke rumah sakit tersebut akan diubah menjadi lebih positif yaitu subjek menjadi berani kontrol ke rumah sakit.

Pada subjek kedua juga demikian. Sebelumnya subjek tidak mau memakai alat bantu pendengaran karena takut dan malu saat orang lain melihat, memiliki perasaan tidak berharga, dan menganggap dirinya sebagai manusia cacat. Pemikiran tersebut memunculkan konsekuensi, yaitu subjek menolak untuk memakai alat bantu. Perilaku-perilaku yang tidak adaptif ini dengan menggunakan exposure diubah menjadi perilaku positif dan lebih adaptif, yaitu subjek mau menggunakan alat bantu pendengarannya.

Hasil dari exposure ini adalah subjek mampu mengubah perilakunya menjadi lebih postif dan adaptif. Tentu saja, exposure yang dilakukan selalu berdampingan dengan pemberian relaksasi dan restrukturisasi kognitif.

3. Tingkat Kecemasan Subjek berdasarkan SUDs

Berdasarkan pada grafik 1 di bawah, dapat dilihat adanya penurunan tingkat kecemasan. Penurunannya terjadi secara bertahap dan perlahan-lahan dari tiap sesi.

Pada sesi awal terjadi penurunan tingkat kecemasan untuk beberapa situasi, tetapi hanya 5 poin saja. Penurunan tersebut terjadi saat sesi 1 dan 2 ketika diberikan latihan terapi relaksasi via letting go. Sebelum diberikan latihan relaksasi subjek sering merasakan reaksi fisik dari kecemasan, misalnya gemetar, berkeringat, sering meremas-remas tangan, kepala pusing, tangan dan kaki kesemutan, dan munculnya gangguan 
tidur atau mimpi buruk. Selain itu pada situasi-situasi tertentu, misalnya saat makan, minum obat, dan saat diajak kontrol kesehatan subjek memiliki perasaan yang tidak nyaman, gelisah, khawatir, dan bingung. Pada situasi tersebut subjek tidak tahu harus berbuat apa untuk mengatasi permasalahannya tersebut. Setelah mendapatkan latihan relaksasi, subjek mampu mengontrol perasaan yang membuatnya tidak nyaman dan mampu berada pada situasi rileks. Hal ini juga diikuti oleh penurunan reaksi kecemasan pada beberapa situasi lainnya. Meskipun penurunannya tidak begitu banyak, subjek mampu mengatasi kecemasannya. Subjek mampu menerapkan latihan relaksasinya ketika berada pada situasi yang menurutnya mengancam dan membuat tidak nyaman. Pada sesi selanjutnya subjek sudah terampil melakukan relaksasi sehingga dapat membantu kelancaran dan keberhasilan terapi selanjutnya.

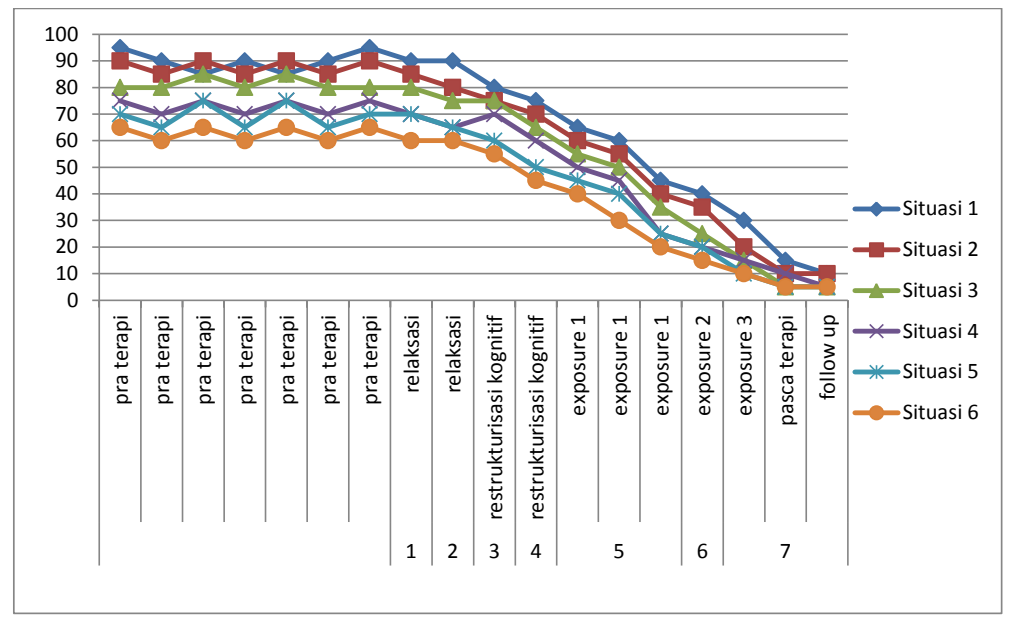

Gambar 1. Tingkat Kecemasan Subjek 1

Selanjutnya mulai dari sesi ke 3 pemikiran negatif ke pemikiran yang terjadi penurunan secara drastis pada positif, rasional, dan sehat. Hasil lain setiap sesinya. Pada sesi ini diberikan latihan restrukturisasi kognitif sampai pada sesi ke 4. Pada kedua sesi ini juga masih diterapkan relaksasi via letting go, yaitu pada awal sesi dan ketika subjek menunjukkan kecemasan. Untuk penurunan tingkat kecemasan sangat berkaitan erat dengan perubahan yang diperoleh, yaitu kondisinya semakin membaik dan lebih rileks.

Sesi ke 5 sampai ke 4 tingkat kecemasan turun semakin drastis. Kecemasan turun hingga mencapai yang paling rendah yang berkisar dari 10-30. Hal ini dikarenakan pada sesi ini mulai dilatihkan exposure secara langsung 
pada situasi yang menurut subjek dapat memunculkan perasaan cemasnya. Penurunan tingkat kecemasan cepat terjadi pada situasi saat jalan-jalan pagi atau akan keluar rumah dan akan makan. Secara bertahap subjek mampu melakukan exposure secara bertahap dari situasi yang membuat tingkat kecemasan paling rendah sampai ke paling tinggi. Penurunan tingkat kecemasan secara drastis pada beberapa sesi terakhir dikarenakan subjek sudah terbiasa dengan teknik relaksasi via letting go dan restrukturisasi kognitif yang sudah diberikan. Selain itu subjek selalu diberikan tugas rumah untuk menerapkan teknik terapi secara mandiri. Subjek juga harus melaporkan hasil penerapan teknik terapi tersebut dalam lembar self monitoring. Dari hasil self monitoring diketahui bahwa subjek menerapkan teknik terapi minimal dua kali sehari. Sampai pada sesi pascaterapi subjek sudah tidak diberikan terapi karena kondisinya sudah membaik, pemikiran negatif sudah berkurang dan dapat dikontrol. Pada beberapa situasi yang sebelumnya berpotensi memunculkan kecemasan, setelah mendapatkan rangkaian terapi sudah berkurang reaksi kecemasannya.

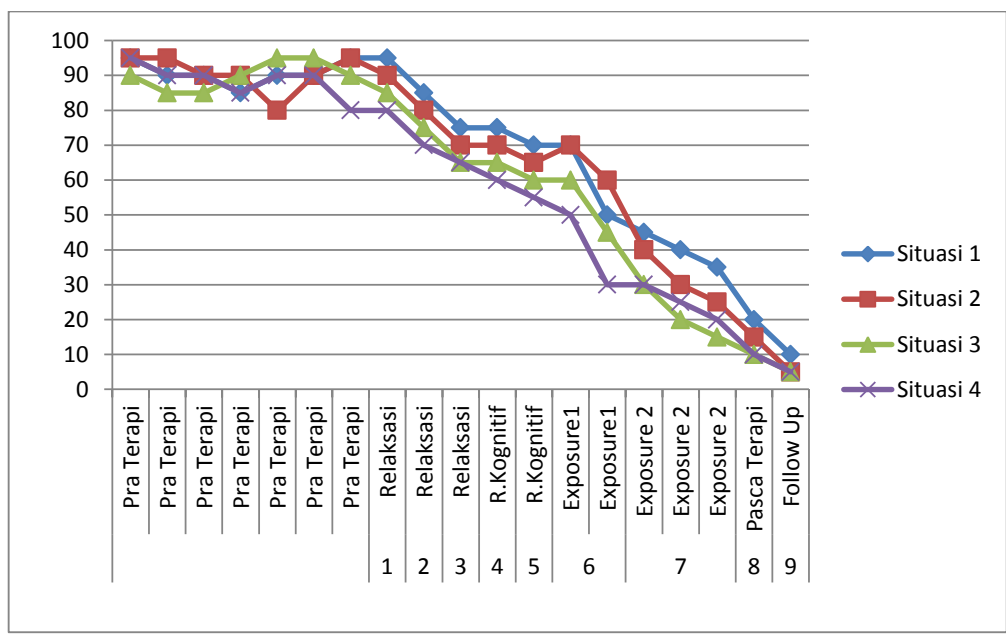

Gambar 2. Tingkat Kecemasan Subjek 2

Berdasarkan pada grafik di atas dapat diketahui penurunan tingkat kecemasan subjek selama mengikuti terapi kognitif perilaku pada setiap sesinya. Berkurangnya tingkat kecemasan tersebut ditandai oleh angka tingkat kecemasan yang semakin menurun.
Secara umum penurunan tingkat kecemasan subjek terjadi secara bertahap dan konsisten. Setiap sesinya terjadi penurunan rata-rata lima poin. Hal ini dapat dilihat pada sesi 1 sampai sesi 3, saat subjek sudah mendapatkan latihan terapi relaksasi. Relaksasi dapat membuat 
subjek berada pada kondisi rileks dan nyaman sehingga dapat mengurangi reaksi kecemasan yang muncul. Hasil dari relaksasi dapat dirasakan subjek, yaitu reaksi fisik sebagai akibat munculnya kecemasan mulai berkurang, misalnya jantung berdebar-debar, kepala pusing, mudah capek dan lemas, mudah menangis dan marah, dan susah tidur.

Berbeda dengan sesi 1 sampai sesi 3, untuk sesi 4 tingkat kecemasan subjek cenderung menetap. Pada sesi ini subjek mendapatkan latihan restrukturisasi kognitif dan tetap diminta untuk melakukan relaksasi. Tingkat kecemasan yang relatif tetap ini berkaitan dengan pemberian restrukturisasi pertama kali saat subjek masih belum mampu untuk mengubah dan melawan pemikiran-pemikiran negatifnya. Akibatnya, subjek merasa bingung dan merasa pesimis dapat menerapkan terapi restrukturisasi kognitif. Setelah mendapatkan penjelasan dan belajar dari beberapa contoh kasus lainnya, subjek mulai mengerti proses terapi ini. Hasilnya pada situasi saat suami mengajak ke fisioterapi, subjek mampu mengubah pemikiran negatifnya menjadi pemikiran yang lebih positif, rasional, dan sehat. Akhirnya tingkat kecemasannya juga menurun dari 65 menjadi 60 , sedangkan untuk situasi yang lainnya masih tetap. Saat diberikan terapi restrukturisasi kognitif ini penurunannya terlihat pada sesi 5, yaitu pada setiap situasi rata-rata mengalami penurunan tingkat kecemasan.
Pada sesi 6, tingkat kecemasan secara keseluruhan menetap bahkan mengalami peningkatan lima poin. Hal ini disebabkan pada sesi ini mulai diajarkan untuk melakukan exposure. Terapi ini menghadapkan subjek pada situasi yang memunculkan kecemasan secara nyata. Meskipun dihadapkan pada situasi nyata secara bertahap, subjek menunjukkan tingkat kecemasan yang lebih tinggi pada sesi sebelumnya. Hal ini berkaitan dengan ketakutan dan kekhawatiran subjek ketika benar-benar berada pada situasi nyata yang dapat memunculkan kecemasan. Selain itu, saat berada di situasi nyata subjek tidak mampu memunculkan pemikiran positifnya sehingga yang muncul adalah pemikiran negatif. Setelah melakukan relaksasi dan restrukturisasi kognitif, subjek mampu melawan dan mengubah pemikiran negatifnya. Akhirnya mampu melakukan exposure dengan baik. Hasilnya tingkat kecemasan pada sesi ke 6 sampai 10 mengalami penurunan yang drastis. Penurunan itu terjadi pada setiap situasi. Sebelum mendapatkan exposure tingkat kecemasannya berkisar antara 5070, setelah memperolehnya turun dan berada pada angka 15-35.

Hasil tersebut tetap mengalami penurunan sampai fase pasca terapi dan tindak lanjut. Pada fase tindak lanjut tingkat kecemasan subjek berada pada kategori rendah yang berkisar antara ngka 5-10. Hasil akhirnya adalah pemikiran negatif dan reaksi kecemasannya jauh berkurang. Subjek juga mengatakan 
bahwa terapi yang diberikan mampu membantunya mengatasi kecemasan yang selama ini dirasakan

\section{Tingkat Kecemasan berdasarkan BAI}

Dari grafik di atas tingkat kecemasan subjek pertama ditunjukkan oleh grafik berwarna hijau-merah. Untuk subjek kedua tingkat kecemasan ditunjukkan dengan grafik berwarna merah mudabiru. Berdasarkan pada tabel dan grafik di atas dapat dilihat perkembangan tingkat kecemasan subjek PM dan MS.

Pada subjek pertama (PM) garis dengan warna hijau memperlihatkan tingkat kecemasan subjek berdasarkan pada skala BAI yang diberikan saat praterapi, pascaterapi, dan tindak lanjut. Selanjutnya warna merah menunjukkan tingkat kecemasan pada saat terapi. Secara lebih jelas dan rinci dapat dilihat dari hasil pengukuran tingkat kecemasan dengan menggunakan SUDs pada grafik 4.1 karena skala pengukuran yang digunakan pada saat terapi adalah SUDs.

Dari grafik tersebut dapat dilihat bahwa terjadi penurunan tingkat kecemasan secara bertahap. Pada praterapi tingkat kecemasan subjek masih berada pada kategori yang sangat tinggi pada angka 54-61. Kemudian tingkat kecemasan mengalami penurunan saat sesi terapi, pascaterapi, dan berlanjut pada fase tindak lanjut. Tingkat kecemasan fase pascaterapi berada pada angka 8 dan fase tindak lanjut berada pada angka 5-6 pada kategori normal.

Untuk subjek kedua tingkat kecemasan ditunjukkan oleh garis merah muda-biru. garis warna merah menunjukkan tingkat kecemasan diukur dengan menggunakan skala BAI. Sedangkan warna biru menunjukkan tingkat kecemasn diukur dengan menggunakan skala SUDs.

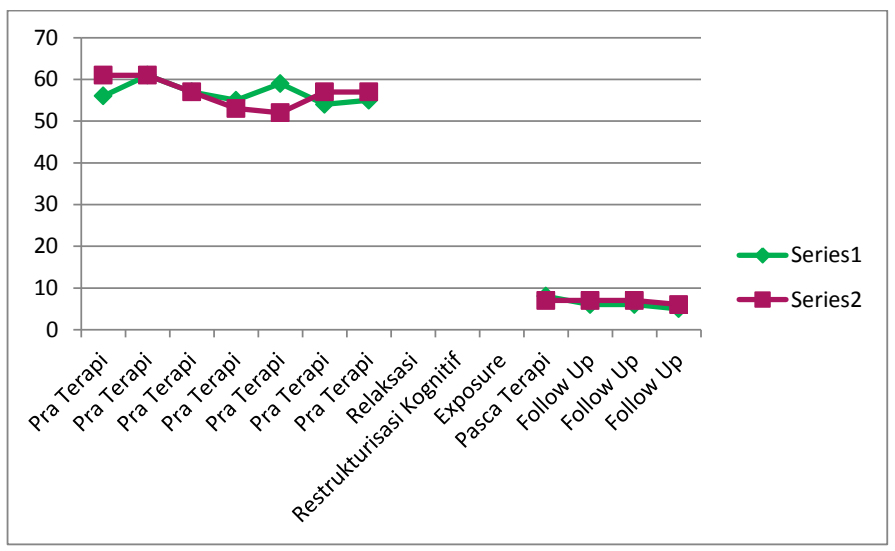

Gambar 3. Penurunan Tingkat Kecemasan Subjek PM dan MS 
Berdasarkan pada tabel dan grafik di atas, dapat dilihat bahwa tingkat kecemasan subjek kedua ini mengalami penurunan. Pada fase pra terapi tingkat kecemasan subjek berkisar pada angka 5261 dan masuk dalam kategori kecemasan tinggi. Selanjutnya mulai turun pada fase terapi dan pasca terapi. Pada pasca terapi turun pada angka 7 dalam kategori tingkat kecemasan rendah atau normal. Penurunan terus terjadi dan bertahan dalam kategori tingkat kecemasan rendah pada fase tindak lanjut. Hal tersebut berarti terapi kognitif perilaku berhasil menurunkan tingkat kecemasan subjek.

\section{PEMBAHASAN}

Data penelitian menunjukkan bahwa terapi kognitif perilaku dapat membantu subjek dalam menangani dan mengurangi gejala-gejala kecemasan terhadap penyakit stroke yang dialaminya. Hal ini tidak terlepas dari teknik-teknik terapi yang diberikan kepada subjek, yaitu relaksasi via letting go, restrukturisasi kognitif, dan exposure. Berdasarkan penjelasan teknik terapi terapi kognitif perilaku di atas, dalam penelitian ini ketiga teknik dilakukan secara berurutan, yaitu relaksasi via letting go, restrukturisasi kognitif, dan exposure with response prevention. Relaksasi via letting go diberikan lebih dahulu supaya subjek merasakan tenang, rileks, dan mampu diajak memahami permasalahannya. Setelah itu diberikan restrukturisasi kognitif, yaitu subjek diajak untuk berpikir dan memahami permasalahannya lebih lanjut, mampu mengubah pemikiran negatifnya. Terakhir, exposure with response prevention diberikan yaitu subjek dihadapkan pada situasi nyata yang dapat memunculkan kecemasan. Pada saat dihadapkan pada situasi nyata ini, subjek bisa saja memunculkan reaksi kecemasannya. Untuk membantu mereduksi kecemasan saat exposure ini, subjek dapat dibantu dengan menerapkan relaksasi dan restrukturisasi kognitif. Dari penjelasan di atas dapat disimpulkan bahwa relaksasi dan restrukturisasi kognitif itu menjadi syarat untuk pemberian exposure.

Ketiga teknik terapi itu mengacu pada upaya mengatasi gejala-gejala utama kecemasan terhadap penyakit stroke, yaitu kognitif, reaksi fisiologis, reaksi emosional, dan perilakunya. Gejala kognitif dapat meningkatkan rasa takut dan khawatir yang akan mengacaukan kemampuan individu untuk berpikiran jernih. Secara fisiologis, tubuh merespon ketakutan dengan memobilisasi diri untuk bertindak, baik dikehendaki ataupun tidak. Respon fisiologis ini merupakan hasil kerja sistem saraf otonom yang mengendalikan berbagai otot dan kelenjar tubuh (Laidlaw, dkk., 2003).

Dari hasil asesmen, kedua subjek mengalami kecemasan terhadap penyakit strokenya dengan memunculkan gejala kognitif, reaksi fisiologis, emosional, dan perilaku. Dengan melihat kondisi kedua subjek tersebut, untuk pertemuan pertama terapi diberikan teknik relaksasi 
via letting go. Tujuan relaksasi diberikan di awal terapi untuk membantu subjek merasakan suasana perasaan yang tenang, nyaman, dan rileks sehingga mudah untuk memunculkan pola pikir yang positif, rasional, dan sehat. Secara teoritis relaksasi via letting go merupakan relaksasi yang mengajarkan subjek untuk bersikap rileks dan menerapkan ketrampilan baru yang telah diperolehnya disaat merasa cemas setiap saat klien memerlukannya (Durand \& David, 2006).

Hasil relaksasi yang diberikan kepada kedua subjek menunjukkan arah yang positif. Sebelum pemberian relaksasi, subjek menunjukkan reaksi kecemasan, seperti gelisah, merasa tidak nyaman, dan reaksi fisik lain seperti berkeringat, jantung berdebar-debar, sesak nafas, dan sebagainya. Setelah melakukan latihan relaksasi, subjek merasakan tubuhnya menjadi rileks, sedikit merasakan kenyamanan, dan reaksi fisisologis semakin berkurang.

Hasil terapi relaksasi juga diperkuat oleh penelitian yang dilakukan oleh Sauter, dkk., (2009) bahwa beberapa teknik relaksasi seperti otot progresif, relaksasi via tension, dan via letting go mampu membantu responden berada pada kondisi rileks. Responden penelitian yaitu pasien penyakit kanker, hipertensi, jantung, dan penyakit kronis lainnya. Hal ini dapat dijelaskan dari sisi fungsi fisiologis, yaitu kemampuan jantung untuk memompa darah secara efisien ke seluruh tubuh akan menjadi maksimal. Selanjutnya suplai oksigen ke otak juga menjadi lancar yang membantu pemulihan para pasien stroke dan pascastroke. Relaksasi secara teratur juga dapat membantu sirkulasi darah dan oksigen, merangsang perife (anggota gerak) yang lumpuh, dan memperbaiki sistem organ tubuh (Guyton, 1982). Hal tersebut juga terjadi pada kedua subjek. Subjek pertama merasakan nyeri di bagian dada berkurang, tangan dan kaki menjadi tidak kaku serta tidak merasakan kesemutan, dan sakit di daerah belakang kepala jauh berkurang. Sedangkan subjek kedua setelah menjalani relaksasi berturutturut mampu mengendalikan emosi, tangannya menjadi tidak kaku, dengingan di telinga berkurang, merasakan dadanya menjadi lega dan tidak sesak.

Apabila subjek sudah merasakan kondisi yang rileks dan nyaman, selanjutnya subjek diajak untuk memahami permasalahan yang dihadapinya. Pertemuan selanjutnya, subjek diajarkan untuk melakukan restrukturisasi kognitif. Tujuan dari restrukturisasi kognitif ini adalah untuk membantu subjek mereduksi pemikiranpemikiran negatifnya. Pemikiran negatif yang muncul sangat menganggu kehidupan sehari-hari subjek, yaitu subjek pertama berfikir jika jangan-jangan istrinya tidak cinta dan menjauh dari dirinya, pemikiran bahwa strokenya akan kambuh lebih parah, menjalar ke seluruh tubuh, dan tidak dapat disembuhkan, berfikir jika kontrol kesehatan kemudian 
akan tahu kalau tubuh yang lain terkena stroke dan kondisi badannya menjadi turun, beranggapan menjadi manusia paling tidak sempurna karena jalan saja harus tertatih dan pakai alat bantu tongkat, dan berpikiran strokenya menjadi semakin parah jika minum obat sehingga pemikiran-pemikiran tersebut memperparah kecemasan subjek.

Subjek kedua sering berpikir janganjangan suami dan anaknya malu mempunyai istri dan ibu yang lumpuh sehingga takut jika suami dan anak-anaknya semakin menjauh. Subjek berpikiran bahwa semua makanan menyebabkan dirinya sakit stroke sehingga menjadi takut untuk makan, berpikiran jadi manusia cacat dan tidak berguna karena harus pakai alat bantu dengar, dan beranggapan sia-sia saja mengikuti fisioterapi karena kelumpuhannya tidak dapat disembuhkan sampai kapanpun.

Pemikiran negatif yang muncul pada kedua subjek tersebut sesuai dengan pernyataan dari Gordon (1993) dan Rudd, dkk., (2007) bahwa pasien-pasien pasca stroke memiliki kecemasan yang diakibatkan dari pemikiran dan keyakinan yang belum tentu benar. Beberapa pemikiran pasien tersebut disebabkan oleh kondisi fisik yang mengalami perubahan akibat penyakitnya, misalnya pasien mengalami kelumpuhan. Pasien yang tidak dapat menerima kondisinya, akan mengalami ketidakseimbangan fisik, sosial, dan psikologisnya sehingga muncul pemikiran-pemikiran yang negatif. Pemikiran negatif tersebut memunculkan simtom yang berlebihan dan sikap neurotik sehingga kesehatannya menjadi memburuk. Untuk membantu pasien pasca stroke mengendalikan pemikiranpemikiran negatifnya, diterapkan terapi restrukturisasi kognitif.

Menurut Beck (1976), restrukturisasi digunakan untuk mengatasi kecemasan berupa pikiran berulang-ulang yang membuat subjek cemas dan untuk mereduksi kecemasan baik reaksi fisiologis, emosional, dan perilakunya. Demikian halnya dengan penerapan teknik ini pada kedua subjek berkaitan dengan pemikiran-pemikiran negatif subjek tersebut terjadi berulang-ulang karena situasi yang memunculkan kecemasan tersebut ditemui subjek hampir setiap hari.

Langkah yang dilakukan pertama kali adalah meminta subjek untuk mengidentifikasi pemikiran-pemikiran negatif apa saja yang muncul pada situasi-situasi yang membuatnya cemas. Selanjutnya membantu subjek untuk memahami hubungan antara kognitifemosi-fisik-perilaku. Langkah terakhir, yaitu mengubah pemikiran negatif menjadi pemikiran positif, rasional, dan lebih sehat. Berdasarkan data penelitian yang ada dapat dilihat bahwa penurunan tingkat kecemasan dan perubahan pemikiran diawali sejak subjek mendapatkan latihan ketrampilan relaksasi yang dilanjutkan 
dengan teknik restrukturisasi kognitif. Hasil yang diperoleh subjek ini didukung oleh pernyataan beberapa ahli bahwa relaksasi dan restrukturisasi kognitif dapat membantu untuk mengurangi reaksireaksi kecemasan (Dugas, dkk., 2009; Sauter, dkk., 2009; Powell, dkk., 2008).

Peran teknik relaksasi dan restrukturisasi kognitif serta ditambah tugas rumah dapat membantu subjek menjadi lebih siap dalam menghadapi sesi exposure. Hal ini disebabkan pada saat exposure subjek dihadapkan pada situasi nyata yang dapat membuat subjek memunculkan reaksi kecemasan. Untuk mempersiapkan subjek berada pada kondisi nyata yang membuatnya cemas, maka diperlukan latihan relaksasi untuk membantu subjek supaya rileks. Setelah berada pada kondisi rileks, subjek mampu diajak untuk berpikir dan memahami hubungan kognitif-emosi-fisik-perilaku yang memunculkan kecemasan. Hasil akhirnya, subjek mampu memunculkan pemikiran positif, rasional, dan sehat meskipun berada pada kondisi yang mengancam sehingga perilaku subjek juga menjadi lebih adaptif.

Selanjutnya dilakukan teknik exposure with response prevention. Dasar dari penerapan teknik ini adalah kedua subjek memiliki pemikiran dan keyakinan tentang ketakutan dan kekhawatiran sehingga muncul kecemasan. Dari pemikiran dan keyakinan tersebut, subjek akan menghindari bahkan tidak berani berada pada situasi tersebut. Jika subjek dapat mencegah untuk tidak menghindar dari situasi tersebut dan ternyata sesuatu yang dipikirakan dan dikhawatirkannya tidak terjadi, hal ini dapat membantu dalam mengubah keyakinan individu (Davison \& Neale, 1994). Oleh karena itu pemberian kedua teknik ini sebelum teknik exposure lebih efektif. Hal ini yang terjadi pada kedua diri subjek, dengan melakukan exposure berkali-kali, maka subjek diajak untuk berlatih melawan pemikiran negatifnya ketika dihadapkan pada situasi nyata sehingga subjek mampu berada pada situasi tersebut.

Pada saat menjalani exposure, subjek dapat menerapkan teknik relaksasi via letting go dan restrukturisasi kognitif. Hal ini dikarenakan subjek akan lebih terbantu dan memudahkan ketika harus mencegah pemikiran negatifnya saat exposure. Di samping itu juga sebagai teknik yang membantu subjek dalam melawan gejala-gejala kecemasan yang muncul saat proses exposure. Teknik kognitif yang dikombinasikan dengan teknik exposure sangat efektif dalam menangani kecemasan, seperti kecemasan yang subjek alami ini (Rathus \& Nevid, 1991)

Penerapan teknik exposure dilakukan secara bertahap dan berulangulang. Pada subjek pertama dilakukan sebanyak lima kali dengan pembagian exposure pertama dilakukan dalam tiga tahap, dilanjutkan exposure kedua 
dan ketiga. Sedangkan subjek kedua dilakukan exposure sebanyak dua kali, dibagi exposure pertama dalam dua tahap dan exposure kedua dalam tiga tahap. Pada saat exposure tahap satu dalam pertemuan pertama, kedua subjek belum masih menunjukkan reaksi cemas dan belum mampu memunculkan pemikiran positif sehingga subjek belum mampu melakukan exposure. Selanjutnya pda pertemua selanjutnya subjek mampu melakukan exposure karena subjek merasakan rileks ketika berada pada situasi yang awalnya mengancam.

Penerapan exposure yang dilakukan berulang-ulang sesuai dengan pernyataan dari Rathus dan Nevid (1991) bahwa semakin sering exposure dilakukan, klien akan semakin nyaman dan semakin menemukan bahwa pemikiran, keyakinan, maupun interpretasinya selama ini belum tentu benar dan berlebihan. Hasil exposure yang dilakukan berulangulang yaitu pemikiran-pemikiran negatif subjek mampu diubah dan dilawan dengan pemikiran yang positif, rasional, dan lebih sehat. Selain itu dapat dilihat dari menurunnya frekuensi munculnya pemikiran negatif subjek dari hari ke hari sampai pada fase pemberhentian terapi.

Keberhasilan subjek dalam menangani kecemasan terhadap penyakit yang dialaminya tidak dapat dilepaskan dari adanya keinginan yang kuat dari dalam diri subjek untuk dapat sembuh. Selain itu juga ditunjang oleh kesediaan subjek sendiri untuk mengikuti terapi setiap sesinya, motivasi yang kuat untuk berubah, dan keaktifan untuk terlibat secara penuh selama menjalani sesi terapi termasuk belajar untuk menerapkan ke situasi-situasi di luar fokus terapi.

Pada dasarnya teknik-teknik terapi, yaitu relaksasi via letting go, restrukturisasi kognitif, dan exposure dapat diterapkan sendiri oleh subjek diluar perilaku yang menjadi fokus terapi tanpa bantuan peneliti karena ketrampilan yang telah diberikan kepadanya. Hal ini sesuai dengan pernyataan Oemarjoedi (2003) yang menyatakan perlunya terapis mempersiapkan tindakan-tindakan profesional untuk mengatasi adanya ketergantungan subjek terhadap terapis (transference) dengan memberikan latihan self-help bagi subjek untuk dapat membantu subjek mengatasi permasalahannya secara mandiri

\section{SIMPULAN DAN SARAN}

\section{Simpulan}

Hasil penelitian ini menunjukkan bahwa terapi kognitif perilaku mampu mereduksi kecemasan secara signifikan pada pasien pasca stroke dengan melihat penurunan tingkat kecemasan. Penurunan tingkat kecemasan berdasarkan pada hasil Subjective Units of Discomfort Scale (SUDs) dan Beck Anxiety Inventory (BAI) selama proses terapi dan tindak lanjut. Selain itu juga dengan melihat dan mengidentifikasi perubahan pada aspek 
pikiran, perasaan, fisiologis, dan perilaku subjek.

Perubahan-perubahan yang dialami subjek setelah menjalani proses terapi ini adalah teknik relaksasi via letting go, restrukturisasi kognitif, dan exposure dapat mereduksi kecemasan terutama kecemasan terhadap penyakit stroke yang dialami kedua subjek. Keberhasilan ini dapat ditandai dengan penurunan tingkat kecemasan dari hasil SUDs dan BAI. Perubahan lain adalah dari pemikiran negatif subjek pada beberapa situasi menjadi perubahan yang positif, rasional, dan sehat.

\section{Saran}

Selanjutnya, beberapa keterbatasan dalam penelitian ini dapat dijadikan acuan untuk melakukan penelitian selanjutnya dengan penyempurnaan keterbatasan penelitian ini. Beberapa hal yang diperlukan adanya pemberian saran terhadap hasil penelitian yaitu:

1. Bagi peneliti selanjutnya diharapkan lebih dapat mempersiapkan diri dengan membekali diri berupa pengetahuan-pengetahuan mengenai penerapan teknik terapi yang akan diberikan sehingga diharapkan tidak terjadi hambatan dalam pelaksanaan proses terapi. Bagi peneliti selanjutnya, dalam melakukan terapi hendaknya tetap menggunakan supervisi yang memahami penerapan teknik-teknik terapi kognitif perilaku.
2. Relaksasi via letting go, restrukturisasi kognitif, dan exposure dapat direkomendasikan sebagai salah satu terapi untuk membantu mengurangi pemikiran negatif yang terjadi pada penderita dengan memiliki kecemasan.

\section{DAFTAR PUSTAKA}

Beck, A. T. (1976). Cognitive Therapy and The Emotional Disorders. England: Penguins Books Ltd.

Blackburn, I-M., \& Davidson, K. (1994). Terapi Kognitif Untuk Depresi dan Kecemasan: Suatu Petunjuk Bagi Praktisi (Rusdakoto Sutadi, Penerjemah). Semarang : IKIP Semarang Press.

Bogousslavsky, J. (2002). Emotions, Mood, and Behavior After Stroke. Journal of The American Hearth Association, 34, 1046-1050.

Brunner, L.S. \& Suddarth, D.S. (1996). Textbook of Medical-Surgical Nursing. USA: Lippincott-Raven Publishers.

Chen, W.C., Chu, H., Lu, R.B., Chou, Y.H., Chen, C.H., Chang, Y.C., O'Brien, A.P., \& Chou, K.R. (2008). Efficacy of Perogressive Muscle Relaxation Training in Reducing Anxiety in Patients With Acute Schizophrenia. Journal of Clinical Nursing, 18(15):2187-96. 
Davison, G.C. \& Neale, J.M. (1994). Abnormal Psychology. New York: John Wiley \& Sons Inc.

Dugas, M.J., Francis, K., Bouchard, S. (2009). Cognitive Behavioral Therapy and Applied Relaxation for Generalized Anxiety Disorder: A time Series Analysis of Change in Worry and Somatic Anxiety. Author Manuscript, 38 (1), 29-41.

Durand, V.M. \& David H. Barlow. (2006). Essentialts of Abnormal Psychology. USA: Thomson Wadsworth

Fausiah, F. \& Widury, J. (2005). Psikologi Abnormal Klinis Dewasa. Jakarta: UI Press.

Friedman, H. S. \& Miriam W. S. (2006). Classic Theories and Modern Research. California: Pearson Education Inc.

Gordon, N. F. (1993). Stroke Your Complete Exercise Guide. USA: Lippincott-Raven Publishers.

Greenberg, L. S. (2002). Emotion-Focused Therapy (Coaching Clients to Work Through Their Feelings). Washington: American Psychological Association.

Guyton, A. C. (1982). Human Physiology and Menchanism of Disease. USA: Saunders Company.
Kalat, J. W. (2007). Biological Psychology (9th ed.). Australia: Thomson Wadsworth.

Kazdin, A. E. (1998). Research Design in Clinical Psychology. Washington DC : American Psychological Association.

Laidlaw, K., Thompson, L.W., GallagherThompson, D. \& Dick-Siskin, L. (2003). Cognitive Behavior Therapy With Older People. England: John Wiley \& Sons Ltd.

Lazarus, R. S. (1991). Emotion and Adaptation. New York: Oxford University Press.

Martin, G. \& Pear, J. (2007). Behavior Modification What It and How Do It. Eight Edition. New Jersey: Pearson Prentice Hall.

Masskulpan, P., Riewthong, K, Dajpratham, P., \& Kuptniratsaikul, V. (2008). Anxiety and Depressive Symptoms After Stroke in 9 Rehabilitations Centers. Journal of Medical Association -Thailand, 91 (10), 595-602.

Newman, M.G., Castonguay, L.G., Borkovec, T.D., Fisher, A.J., and Samuel S. Nordberg, S.S. (2008). An Open Trial of Integrative Therapy for Generalized Anxiety Disorder. Journal of Psychotherapy, 45 (2), 135-147. 
Oemarjoedi, A. K. (2003). Pendekatan Cognitive Behavior dalam Psikoterapi. Jakarta: Penerbit Creative Media.

Ormrod, J. E. (2004). Human Learning (4th ed.). New Jersey : Pearson Education, Inc.

Otto, M.W., Smits, J.A., \& Reese, H.E.. (2004). Cognitive Behavioral Therapy for Treatment of Anxiety Disorders. Journal of Clinical of Psychiatry. 65 (5), 34-41.

O'Donohue, W. T. \& Fisher, J. E. (2008). Cognitive Behavior Therapy. New Jersey: John Willey \& Sons, Inc.

Pandji, D. (2011). Stroke Bukan Akhir Segalanya. Jakarta: Elex Media Komputindo.

Persons, J.B. (2008). The Case Formulation Approach To Cognitive-Behavior Therapy. New York: The Guilford Press.

Powell, V.B., Abreu, N., Oliveira, I.R., \& Sudak, D. (2008). Cognitive Behavioral Therapy for Depressions. Clinical Case Studies, 3 (2), 73-80.

Rathus, S. A. \& Nevid, J. J. (1991). Abnormal Psychology. New Jersey: Prentice Hall.
Rudd, A., Irwin, P., \& Penhale, B. (2007). Stroke at Yours Fingertips. London: Class Publishing.

Sari, W, Indrawati, L., \& Dewi, C.S. (2008). Care Yourself: Stroke. Jakarta : Penebar Plus+.

Sauter, F.M., Heyne, D., \& Westenberg, P.M. (2009). Cognitive Behavior Therapy for Anxious Adolescents: Developmental Influences on Treatment Design and Delivery. Clinical Child Family Psychology. 12, 310-335.

Splieger, M. D \& Guevremont, D. C. (2003). Contemporary behavior therapy. Fourt Edition. USA : Thompson Wadsworth.

Stekee, G \& Neziroglu, F. (2003). Assessment of ObsessiveCompulsive Disorder and Spectrum Disorder. Brief Treatment and Crisis Intervention. 3 (2), 169-185.

Thomas, S. A.\& Lincoln, N. B. (2008). Predictors of Emotional Distress After Stroke. Journal of The American Hearth Association. 39, 1240-1245.

Tjokroprawiro, A. (2007). Buku Ajar IImu Penyakit dalam Fakultas Kedokteran Universitas Airlangga. Surabaya: Airlangga University Press. 